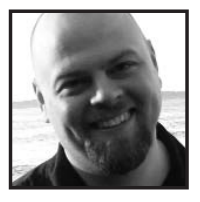

\title{
Free Yourself From the Role
}

\author{
Dale Boyle, McGill University
}

\section{ABSTRACT}

The author shares a song he wrote to represent his views about the movement among educators to redefine for themselves their roles and practices. He also reflects on his song-writing process. The song and accompanying reflection serve to question stereotypical views of knowledge and suggest the need for educators to embrace a more artful approach to teaching and learning.

\section{Free Yourself From the Role}

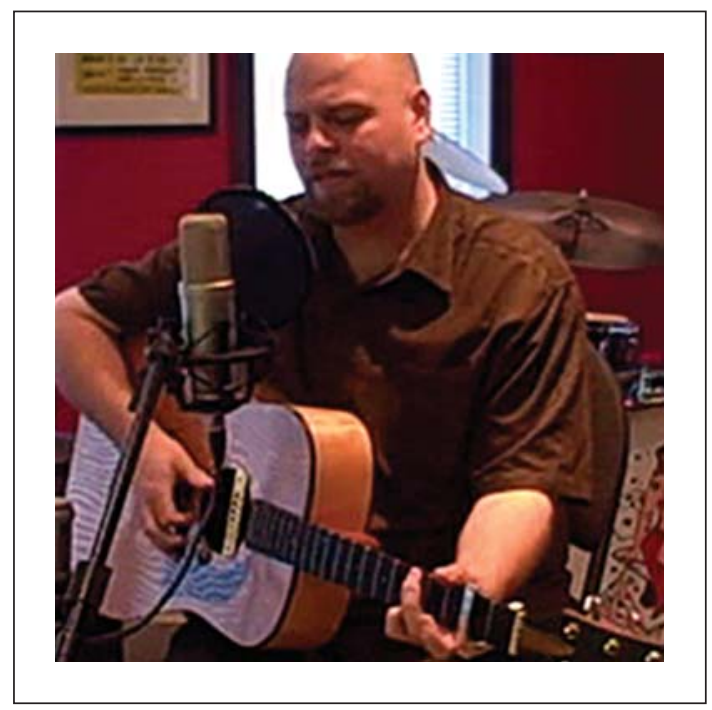

(Press here to see and hear Dale perform.) 
Free yourself from the role;

The one they set for you before you were born

That dictates every move you should make and the ideals you should hold Within a play, a poem, or song,

Or a painting some would hang on a wall;

There's a voice that will call

Free yourself from the role

So come on in;

There ain't no need to check your past at the door;

No one is going to make you sit at a desk nailed to the floor;

There's an old man in a white coat

Setting sail in a sinking boat;

The old ways no longer float

Free yourself from the role

The one they set for you before you were born

That dictates every move you should make and the ideals you should hold Within a play, a poem, or song,

Or a painting some would hang on a wall;

There's a voice that will call

Free yourself from the role

Free yourself from the role

Free yourself from the role

wrote Free Yourself From the Role to portray my understanding of how teachers and researchers are currently redefining themselves and their practices. The song shares how they are incorporating a more artful approach to their work, one that breaks away from a scientific tradition that historically silenced individual voices in the interests of a narrow, stereotypical view of knowledge.

I began the song-writing process by exploring various chord structures on the guitar while simultaneously searching for melodic ideas. Once I settled on an idea I wrote rough lyrics for the first verse, and this enabled me to explore different tempos, phrasings, and chord structures. It helped to clarify a mood and provided further direction. A lyric that had emerged earlier on resonated with me as I reflected upon how researchers and teachers are redefining themselves and their practice on their own terms. I chose to open and close the first verse with "Free yourself from the role." 
I also used the following lines, "The one they set for you before you were born, That dictates every move you should make and the ideals you should hold" to further qualify the concept of "role." Redefining oneself as a researcher and/or teacher can require breaking away from a long-imposed tradition. These lines became the overriding statement of the entire piece.

I wanted to make some reference to a nontraditional way of seeing and understanding the world - an artful way of seeing. This inspired the line "Within a play, a poem, or song, Or a painting some would hang on a wall." It is quite literal, and I later contrasted this with a more metaphorical second verse. "There's a voice that will call," alludes to those who have been silenced in research. The verse ends by emphasizing "Free yourself from the role."

As I reflected upon my experiences as a student in a rigid system where my interests were divorced from the classroom, I wrote the optimistic lines that open the second verse, "So come on in; There ain't no need to check your past at the door. No one is going to make you sit at a desk nailed to the floor."The following lines, "There's an old man in a white coat, Setting sail in a sinking boat, The old ways no longer float," were inspired by the stereotypical notion of what constitutes knowledge and good science. The "old man" reflects a past that valued male-dominated research. The "white coat" is likewise inspired by the stereotype of what a scientist was thought to look like-someone, usually a male, in a lab coat. The "sinking boat" is the rigid view of knowledge, and the "old ways," the narrow ways of seeing the world, no longer stand, or "float." The second verse also ends with "Free yourself from the role" and from this last line I flow directly back to repeating the opening verse, which served to bookend the piece. By repeating the opening verse I reinforce the point that one should feel empowered to break from tradition and give voice to those who would otherwise be silenced.

The interplay of words, music, and melody allowed me to deliver a message, and to evoke the feeling of that message. Like others who best express themselves in artful ways, it felt liberating to do so. That is the message of my song, Free Yourself From the Role. 


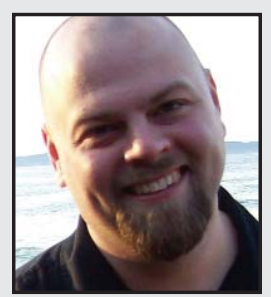

Dale Boyle is a doctoral candidate in the Department of Integrated Studies in Education at McGill University. He is also a Gaspé-born, Montreal-based roots music recording artist and songwriter. He has been called "one of the best to emerge from north of the border" (Americana Homeplace) and "an accomplished musician, a fine singer, and an exceptionally thoughtful, meticulous songwriter" (Canadianblues.ca). He is the winner of the Lys Blues "Folk/Blues Artist of the Year" award (2005 and 2006), International Narrative Song Competition award (2007), and Lys Blues "Songwriter of the Year" award (2008). Dale's latest recording, Small Town van Gogh, has received rave reviews internationally, and has appeared on the Euro Americana Chart. Dale has performed his music at home and abroad, from the Montreal International Jazz Festival to the Mississippi Sunflower Gospel and Blues Festival. 